\title{
KORELASI KETERAMPILAN PENGUASAAN DIKSI DENGAN KETERAMPILAN MENULIS TEKS CERPEN SISWA KELAS X SMAN 2 HARAU
}

\section{Proposal Penelitian}

Dibuat untuk memenuhi tugas akhir mata kuliah Metode Penelitian Pembelajaran Bahasa Indonesia yang diampu oleh Prof. Dr. Syahrul. R., M.Pd.

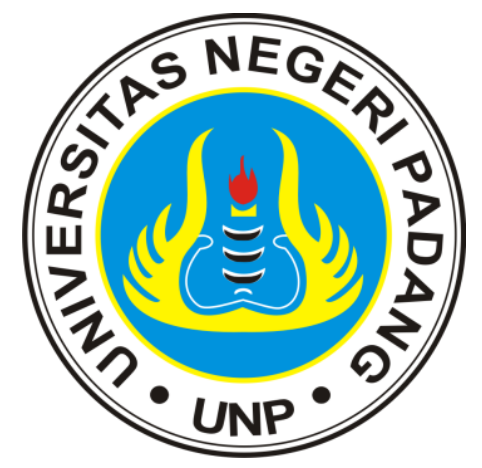

Hanifah Azzahra

NIM 19016092

PROGRAM STUDI PENDIDIKAN BAHASA INDONESIA JURUSAN BAHASA DAN SASTRA INDONESIA DAN DAERAH FAKULTAS BAHASA DAN SENI UNIVERSITAS NEGERI PADANG 


\section{DAFTAR ISI}

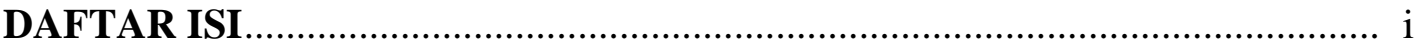

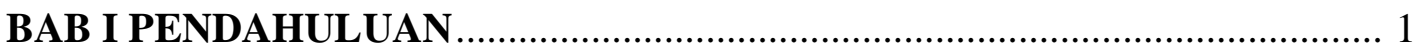

A.Latar Belakang Masalah...................................................................... 1

B. Identifikasi Masalah ............................................................................ 3

C. Batasan Masalah ........................................................................................ 3

D. Rumusan Masalah ............................................................................ 3

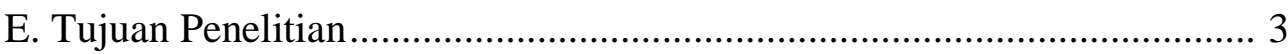

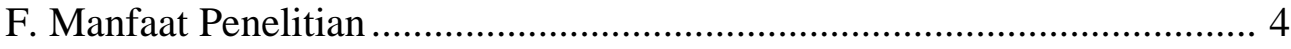

G. Definisi Operasional ........................................................................... 4

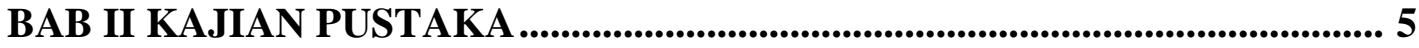

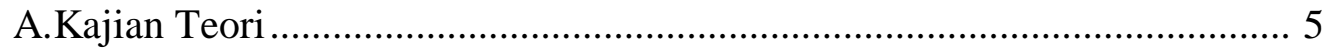

1.Keterampilan Menulis Teks Cerpen ................................................... 5

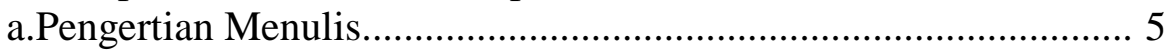

b. Pengertian Teks Cerpen .............................................................. 5

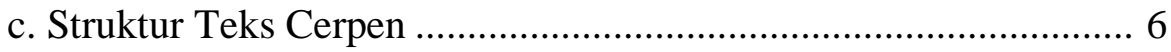

d. Unsur-Unsur Teks Cerpen ........................................................... 7

e. Kaidah Kebahasaan Teks Cerpen................................................... 8

f. Langkah-Langkah Menulis Teks Cerpen.................................... 9

g. Teknik Penilaian Teks Cerpen .................................................. 10

2.Hakikat Penguasaan Diksi ............................................................... 11

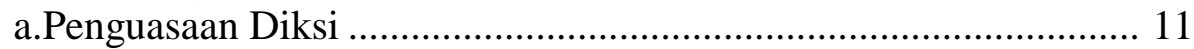

b. Indikator Penguasaan Diksi ........................................................... 12

3.Korelasi Penguasaan Diksi dengan Keterampilan Menulis Teks ......... 12

B. Kerangka Konseptual ......................................................................... 12

C. Hipotesis Penelitian ....................................................................... 13

BAB III METODELOGI PENELITIAN_...................................................... 14

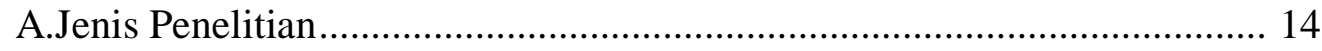

B. Populasi dan Sampel ..................................................................... 15

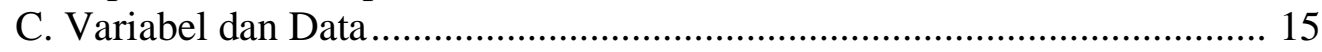

D. Instrumen Penelitian ............................................................................ 15

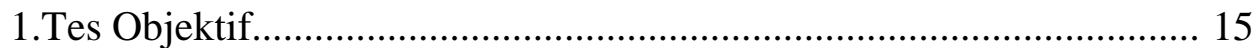

2. Tes Unjuk Kerja .......................................................................... 16

E.Teknik Pengumpulan Data .............................................................. 16

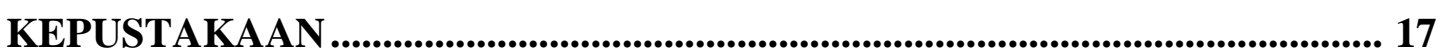




\section{BAB I \\ PENDAHULUAN}

\section{A. Latar Belakang Masalah}

Keterampilan berbahasa memiliki empat aspek keterampilan yaitu keterampilan menyimak, berbicara, membaca, dan menulis. Dari keempat aspek tersebut keterampilan menulis lebih sulit dikuasai karena keterampilan menulis harus menguasai berbagai unsur, baik unsur kebahasaan maupun unsur isi. Menulis merupakan aktivitas pengekspresian ide, gagasan, pikiran atau perasaan dalam lambang kebahasaan (Sukirman, 2020). Kegiatan menulis merupakan suatu kegiatan yang aktif dan produktif serta memerlukan cara berpikir yang teratur yang diungkapkan dalam bahasa tulis (Rachman, Anita Kurnia \& Lutfiyah, 2020). Kegiatan ini melibatkan aspek penggunaan tanda baca dan ejaan, penggunaan diksi dan kosakata, penataan kalimat, pengembangan paragraf, pengolahan gagasan serta pengembangan model karangan. Semakin menguasai aspek tersebut maka semakin mudah juga dalam menulis sebuah karya. Sebagai suatu keterampilan berbahasa, menulis merupakan kegiatan yang kompleks karena penulis dituntut untuk dapat menyusun dan mengorganisasi isi tulisan serta menuangkannya dalam ragam bahasa tulis (Kartini, 2017). Melalui kegiatan menulis, seseorang akan mampu mengungkapkan pikiran, ide, dan gagasan kepada orang lain baik dalam bentuk ilmiah seperti jurnal maupun makalah ataupun bentuk sastra seperti novel, cerpen, puisi, dan drama. Dari berbagai bentuk karya sastra tersebut, peneliti tertarik pada keterampilan menulis cerpen. Melalui menulis cerpen siswa dapat menyampaikan ide kreatif serta imajinasi yang ada dalam pikiran mereka kedalam bahasa yang indah dan menghasilkan sebuah cerpen yang unik dan menarik. Cerpen merupakan variasi bacaan yang diharapkan mampu menarik minat siswa karena kisahnya singkat, tidak membutuhkan waktu yang lama saat membacanya, sehingga tidak membuat jenuh saat membacanya (Purwahida, 2017).

Rendahnya kemampuan menulis siswa antara lain disebabkan oleh belum terlaksananya hakikat pembelajaran menulis, proses belajar-mengajar menulis di semua level pendidikan ternyata lebih banyak berpusat pada segala sesuatu tentang menulis (Homsaniwati, 2019). Artinya dalam menulis hal yang utama yang harus diperhatikan adalah bagaimana hakikat menulis tersebut, bagaimana proses berpikir yang teratur sehingga apa yang ditulis mudah dipahami pembaca. Hal ini sejalan dengan siswa harus memahami penguasaan diksi dalam menulis, 
karena dengan pemilihan diksi memberikan keunikan dalam sebuah karya sastra. Masalah utama yang dialami mahasiswa dalam menulis cerpen ini adalah kesulitan menemukan dan menggali ide (Fitri et al., 2019).

Kemudian Susetya (2019) mengemukakan bahwa bentuk kesulitan lain adalah kesulitan untuk mengembangkan bahasa agar menjadi tulisan yang menarik. Kemampuan berbahasa indonesia secara tertulis diarahkan agar siswa memiliki kegemaran menulis sehingga mampu meningkatkan pengetahuannya, menyampaikan informasi aktual, menyatakan sikap intelektual, menyatakan sikap moral dan mampu memanfaatkannya dalam kegiatan sehari-hari (Fitriani, 2016). Hal ini sejalan dengan pendapat Sri (2014) bahwa Keterampilan menulis dapat untuk mengembangkan kecerdasan, inisiatif, dan kreativitas seseorang. Selain itu, melalui keterampilan menulis dapat pula ditumbuhkan keberanian, serta merangsang kemauan dan pengetahuan mengumpulkan informasi. Menurut Surastina (2021) salah satu faktor yang mempengaruhi kemampuan berbahasa seseorang, baik secara lisan maupun secara tulisan adalah menguasai diksi dengan baik. Dalam menulis penguasaan diksi sangat berpengaruh kepada tulisan seseorang, menarik atau tidaknya sebuah karya dilihat dari bagaimana penguasaan diksi dalam karya tersebut, semakin penguasaan diksinya tepat maka semakin menarik juga karya tersebut. Pembelajaran menulis cerpen pada umumnya dirasakan sulit oleh siswa. Siswa harus memiliki kosa kata yang cukup, pilihan kata (diksi) yang tepat, serta imajinasi yang cukup tinggi untuk menciptakan sebuah cerpen yang baik (Sarudi, 2018). Keterampilan menulis yang tidak diimbangi dengan praktik menjadi salah satu faktor kurang terampilnya siswa dalam menulis (Nur et al., 2021). Dalam hal ini penulis memilih tulisan karya sastra yaitu menulis cerpen. Tentu dalam menulis cerpen ini akan dipraktikkan langsung nantinya agar menghasilkan cerpen yang bagus dan menarik. Sejalan dengan hal tersebut Silalahi (2017) mengemukakan cerpen yaitu cerita yang bersumber pada persoalan kehidupan, sesuatu nilai kehidupan yang menjadi tema cerita, dari sebuah cerita kita bisa mengambil sebuah pesan yang ditulis oleh seorang pengarang, memiliki nilai- nilai kehidupan baik nilai-nilai agama, moral, dan sosial dalam cerita pendek.

Kemudian Nurgiyantoro (dalam Kurniawan, 2019) mengungkapkan bahwa cerita pendek (fiksi) juga menyajikan berbagai masalah kehidupan manusia dalam interaksinya dengan lingkungan dan sesamanya, dengan diri sendiri, serta 
interaksinya dengan Tuhan. Dengan demikian, karya fiksi berupa cerita pendek sarat akan hikmah dan pembelajaran yang dapat diambil di dalamnya. Selain hal tersebut terkandung pula sebentuk perenungan pengarang melalui penafsiran peristiwa-peristiwa yang terjadi dalam kehidupan. Menurut Nengsi, Y. S., Basri, I., \& Tamsin (2020) sebagian siswa beranggapan bahwa keterampilan menulis teks cerpen sangat sulit. Penyataan tersebut disebabkan oleh empat faktor. Pertama, kurangnya kemampun siswa dalam menulis teks cerpen. Hal ini dapat dilihat dari nilai siswa yang dominan di bawah KKM. Kedua, siswa tidak dapat mengembangkan struktur teks cerpen dengan lengkap. Ketiga, dari segi unsur pembangun teks cerpen, siswa tidak membuat alur dari perkenalan, mulainya terjadi konflik hingga konflik memuncak, penyelesaian konflik, hingga koda atau amanat pada cerita. Keempat, dari segi ciri kebahasaan, siswa masih salah milih diksi yang tepat.

\section{B. Identifikasi Masalah}

Berdasarkan uraian yang telah dikemukakan dalam latar belakang masalah di atas, maka identifikasi masalah dalam penelitian ini adalah rendahnya keterampilan menulis teks cerpen siswa disebabkan oleh faktor keterampilan penguasaan diksi, untuk itu perlu dilakukan penelitian mengenai korelasi keterampilan penguasaan diksi dengan keterampilan menulis teks cerpen.

\section{Batasan Masalah}

Berdasarkan identifikasi masalah tersebut, permasalahan penelitian ini dibatasi pada korelasi penguasaan diksi dengan keterampilan menulis teks cerpen siswa kelas X SMAN 2 Harau.

\section{Rumusan Masalah}

Rumusan masalah dalam penelitian ini adalah sebagai berikut. Pertama, bagaimana keterampilan penguasaan diksi siswa kelas X SMAN 2 Harau. Kedua, bagaimana tingkat keterampilan menulis teks cerpen siswa kelas X SMAN 2 Harau. Ketiga, bagaimana korelasi keterampilan penguasaan diksi dengan keterampilan menulis teks cerpen siswa kelas X SMAN 2 Harau?

\section{E. Tujuan Penelitian}

Berdasarkan rumusan masalah di atas, tujuan penelitian ini adalah sebagai berikut. Pertama, mendeskripsikan keterampilan penguasaan diksi siswa kelas $\mathrm{X}$ SMAN 2 Harau. Kedua, mendeskripsikan tingkat keterampilan menulis teks cerpen siswa kelas X SMAN 2 Harau. Ketiga, mendeskripsikan korelasi 
keterampilan penguasaan diksi dengan keterampilan menulis teks cerpen siswa kelas X SMAN 2 Harau.

\section{F. Manfaat Penelitian}

Manfaat dari penelitian ini adalah sebagai berikut. Pertama, dapat menambah wawasan tentang keterampilan penguasaan diksi dan keterampilan menulis teks cerpen. Kedua, bagi guru, khususnya guru bahasa Indonesia di SMAN 2 Harau, yaitu sebagai bahan masukan dalam meningkatkan hasil belajar teks menulis cerpen. Ketiga, dapat bermanfaat bagi siswa SMAN 2 Harau, yaitu dapat meningkatkan keterampilan penguasaan diksi dan meningkatkan keterampilan menulis teks cerpen.

\section{G. Definisi Operasional}

Untuk menghindari terjadinya kesalahan penafsiran dalam penelitian, maka diberikan definisi operasional sebagai berikut.

1. Korelasi

Korelasi merupakan ikatan atau pertalian yang mengaitkan antara dua hal. Korelasi penelitian ini yaitu seberapa besar keterkaitan penguasaan diksi dengan keterampilan menulis teks cerpen siswa kelas X SMA Negeri 2 Harau.

2. Penguasaan Diksi

Penguasaan diksi dalam penelitian ini adalah bagaimana penguasaan diksi atau pemilihan kata siswa dalam menulis teks cerpen. Penguasaan diksi dapat diukur dengan menggunakan tes objektif.

3. Keterampilan Menulis Teks Cerpen

Keterampilan menulis teks cerpen yang dimaksud adalah keterampilan menuliskan atau memproduksi teks cerpen yang termuat dalam kurikulum 2013. 


\section{BAB II \\ KAJIAN PUSTAKA}

\section{A. Kajian Teori}

Berdasarkan permasalahan penelitian, terdapat tiga teori yang akan diuraikan pada kajian ini. Pertama, keterampilan menulis teks cerpen. Kedua, penguasaan diksi. Ketiga, korelasi penguasaan diksi dengan keterampilan menulis teks cerpen.

\section{Keterampilan Menulis Teks Cerpen}

Teori yang akan diuraikan dalam keterampilan menulis teks cerpen, yaitu (a) pengertian menulis, (b) pengertian teks cerpen, (c) struktur teks cerpen, (d) Unsur-unsur Menulis Teks Cerpen, (e) kaidah kebahasaan teks cerpen, (f) langkah-langkah menulis teks cerpen, (g) teknik Penilaian dalam menulis teks cerpen.

\section{a. Pengertian Menulis}

Pembelajaran menulis mempunyai peranan yang penting dalam pelajaran Bahasa Indonesia (Rosmaya, 2018). Menulis merupakan suatu keterampilan berbahasa yang dipergunakan untuk berkomunikasi secara tidak langsung, tidak secara tatap muka dengan orang lain (Tarigan dalam Khulsum et al. 2018). Menulis pada dasarnya adalah proses untuk mengemukakan ide dan gagasan dalam bahasa tulis (Abidin, 2016).

\section{b. Pengertian Teks Cerpen}

Dalam kurikulum 2013 teks tidak diartikan sebagai bentuk bahasa tulis. Teks itu adalah ungkapan pikiran manusia yang lengkap yang di dalamnya ada situasi dan konteksnya (Mahsun dalam Sufanti et al., 2013). Hartoko dan Rahmanto (dalam Sufanti et al., 2013) mendefinisikan teks adalah urutan teratur sejumlah kalimat yang dihasilkan dan atau ditafsirkan sebagai suatu keseluruhan yang kait mengkait. Pengertian ini mendukung pendapat bahwa teks dapat terdiri dari teks tulis dan lisan.

Cerita pendek merupakan salah satu jenis karya sastra yang cukup popular dengan singkatan cerpen. Cerpen hanya memuat sebuah penceritaan yang memusat pada satu peristiwa pokok, sedangkan peristiwa itu tentu tidak sendiri, ada peristiwa lain yang sifatnya mendukung peristiwa pokok. Cerpen, sesuai dengan namanya, adalah cerita yang pendek. Akan tetapi, berapa ukuran panjang pendek itu memang tidak ada 
aturannya, tidak ada satu kesepakatan di antara para pengarang dan para ahli Nurgiyantoro (dalam Fajar Dwi Cahyaningrum, 2019). Purwadi \& Yulistio (2021) mengungkapkan cerpen merupakan bentuk karya sastra aliran prosa baru yang bersifat fiksi. Prosa merupakan karangan fiksi yang diartikan sebagai rekaan. Oleh karena itu, prosa fiksi yang salah satunya berbentuk cerpen sebagai karya rekaan yang tokoh, peristiwa, dan latarnya digambarkan secara imajinatif atau bersifat khayalan. Cerita pendek (cerpen) adalah suatu bentuk prosa baru berbentuk cerita atau naratif fiktif yang tidak ada aturan baku tentang panjang pendeknya tulisan.

Berdasarkan uraian dari para ahli di atas, dapat disimpulkan bahwa teks cerpen adalah cerita rekaan yang menyajikan satu peristiwa atau masalah yang berpusat pada tokoh sentral. Cerpen dapat dibaca sekitar sepuluh menit atau setengah jam, karena penggunaan kata-katanya sangat ekonomis sekitar 500-5000 kata.

\section{c. Struktur Teks Cerpen}

Seperti genre sastra lain teks cerpen pun memiliki struktur atau unsur-unsur yang mendukung kebulatannya, unsur-unsur ini saling berkaitan sehingga tidak bisa dipisahkan satu sama lainnya. Kosasih (dalam Bagus, 2017), menjelaskan struktur teks cerita pendek secara umum dibentuk oleh.

1) Abstrak (sinopsis) merupakan bagian cerita yang menggambarkan keseluruhan isi cerita.

2) Orientasi atau pengenalan cerita, baik itu berkenaan dengan penokohan ataupun bibit-bibit masalah yang dialaminya.

3) Komplikasi atau puncak konflik, yakni bagian teks cerpen yang menceritakan puncak masalah yang dialami tokoh utama.

4) Evaluasi, yakni bagian yang menyatakan komentar pengarang atas peristiwa puncak yang telah diceritakannya.

5) Resolusi merupakan tahap penyelesaian akhir dari seluruh rangkaian cerita.

6) Koda merupakan komentar akhir terhadap keseluruhan isi cerita, mungkin juga diisi dengan kesimpulan tentang hal-hal yang dialami tokoh utama kemudian.

Dari penjelasan struktur di atas, dapat dijelaskan kembali bahwa 
abstrak adalah menggambarkan keseluruhan isi cerita, namun keberadaan abstrak dalam teks cerpen bersifat opsional, mungkin ada dan mungkin bisa tidak muncul. Orientasi adalah mengenalkan masalah yang dialami tokoh. Komplikasi menceritakan puncak masalah yang dialami tokoh, bagian ini merupakan bagian yang paling menegangkan dan rasa penasaran pembaca tentang cara sang tokoh di dalam menyelesaikan masalahnya bisa terjawab. Evaluasi merupakan komentar atas peristiwa puncak yang diceritakannya, komentar yang dimaksud dapat dinyatakan langsung oleh pengarang atau diwakili oleh tokoh tertentu. Pada bagian resolusi ketegangan sudah lebih mereda, karena bagian ini hanya terdapat masalahmasalah kecil yang tersisa yang perlu mendapat penyelesaian. Kemudian bagian terakhir yaitu koda, bagian ini merupakan komentar akhir keseluruhan isi cerita atau kesimpulan tentang hal-hal yang dialami tokoh utama. Jadi, keenam struktur tersebut saling berkaitan dan mempunyai peranan penting untuk membangun cerita atau karangan yang menarik untuk dibaca oleh pembaca.

\section{d. Unsur-unsur Teks Cerpen}

Unsur-unsur pembangun cerita pendek, seperti berikut.

1) Tema

Stanton dan Kenny (melalui Burhan Nurgiyantoro, 2005: 66) mengartikan tema sebagai makna yang dikandung oleh sebuah cerita. makna tersebut secara khusus menerangkan sebagian unsurnya dengan cara yang sederhana. Usaha menemukan tema suatu karya sastra harus dilakukan melalui pemahaman terhadap cerita dan unsur fiksi. Kejelasan pengertian tema yang digunakan sebagai dasar analisis akan memudahkan penafsiran dan pembuatan pernyataan tema.

2) Alur

Menurut Burhan Nurgiyantoro (2005) plot adalah urutan kejadian/peristiwa dalam sebuah cerita yang disusun oleh pengarang berdasarkan urutan kaitan sebab akibat.

3) Tokoh dan Penokohan

Jones (melalui Burhan Nurgiyantoro, 2005) menyatakan bahwa penokohan adalah pelukisan gambaran yang jelas tentang seseorang yang ditampilkan dalam sebuah cerita. penokohan meliputi pelaku 
cerita, perwatakan tokoh, dan pelukisan tokoh. Tokoh dan penggambaran karakter tokoh yang terdapat dalam cerita pendek bersifat terbatas. Baik karakter fisik maupun sifat tokoh tidak digambarkan secara khusus, hanya tersirat dalam cerita yang disampaikan sehingga pembaca harus mengkontruksikan sendiri gambaran yang lebih lengkap tentang tokoh itu.

4) Latar atau Setting

Abrams (melalui Burhan Nurgiyantoro, 2005) menyatakan bahwa latar adalah landasan tumpu yang menyaran pada pengertian tempat, hubungan waktu, dan lingkungan sosial terjadinya peristiwa. Pelukisan latar cerita dalam cerita pendek jumlahnya terbatas.

5) Sudut Pandang

Menurut Burhan Nurgiyantoro (dalam Darusuprapti, 2015) sudut pandang, point of view menyarankan pada cara sebuah cerita dikisahkan. Sudut pandang merupakan cara atau pandangan yang dipergunakan pengarang sebagai sarana untuk menyajikan tokoh, tindakan, latar, dan berbagai peristiwa yang membentuk karya fiksi kepada pembaca.

6) Gaya Penceritaan

Suharianto (dalam Darusuprapti, 2015) mengatakan bahwa gaya bahasa dalam karya sastra mempunyai fungsi ganda yaitu sebagai alat penyampaian maksud pengarang dan sebagai penyampaai perasaan. Artinya, melalui karya sastra seorang pengarang bukan hanya sekedar bermaksud memberitahukan kepada pembaca mengenai apa yang dilakukan dan dialami tokoh dalam ceritanya, melainkan bermaksud pula untuk mengajak pembacanya untuk ikut merasakan apa yang dilakukan oleh tokoh cerita.

7) Amanat

Waluyo (dalam Darusuprapti, 2015) mengungkapkan amanat, pesan, nasehat merupakan kesan yang ditangkap pembaca setelah membaca cerpen. Amanat dirumuskan sendiri oleh pembaca. Cara menyimpulkan amanat cerpen sangat berkaitan dengan cara pandang pembaca terhadap suatu hal.

\section{e. Kaidah Kebahasaan Teks Cerpen}


Kaidah teks adalah aturan atau patokan yang sudah pasti dalam penulisan sebuah teks. Artinya kaidah teks bertujuan umtuk membedakan kaidah kebahasaan antara teks yang satu dengan berbagai jenis teks yang lainnya. Menurut Kosasih (dalam Bagus, 2017) kaidah teks cerpen sebagai berikut.

1) Teks cerpen pada umumnya menggunakan bahasa tidak baku atau tidak formal.

2) Teks cerpen lebih banyak memotret atau mengisahkan gambaran kehidupan sehari-hari.

3) Banyak dijumpai kalimat yang tidak lengkap strukturnya; bagianbagiannya mengalami pelesapan.

4) Bentuk kalimatnya pendek-pendek, karena terdapat bagian-bagian yang mengalami pelesapan.

Berdasarkan hal tersebut, dapat disimpulkan bahwa dalam teks cerpen terdapat empat karakteristik yang dapat menunjang terbentuknya suatu cerita. Dengan adanya karakteristik tersebut cerita itu bisa terkesan lebih nyata, seolaholah benar-benar terjadi.

\section{f. Langkah-langkah Menulis Teks Cerpen}

Teks cerpen dituntut mempunyai jiwa yang membuat teks cerpen itu sendiri mempunyai daya pikat. Salah satu teknis menulis teks cerpen adalah merekayasa rangkaian cerita menjadi unik, baru dan tentu saja tidak ada duanya. Hidayati (dalam Purwanti, 2016) mengemukakan bahwa langkah-langkah menulis teks cerita pendek adalah sebagai berikut.

1) Tentukan ide, ide bisa didapat dengan berbagai cara, salah satunya adalah membayangkan suatu kejadian yang benar-benar membuat kita terkesan

2) Kemudian carilah tema dan ide tersebut.

3) Menuliskan semua hal yang berhubungan dengan tema yang sudah ditentu-kan.

4) Buatkan kerangka cerita dari awal sampai akhir cerita. Kerangka dibuat berdasarkan semua hal yang berhubungan dengan tema yang sudah ditulis.

5) Periksa kembali kerangka yang sudah dibuat, buanglah kalimatkalimat yang kiranya kurang diperlukan. 
6) Mulailah menulis teks cerpen dengan acuan kerangka yang sudah dibuat. Penulisan teks cerpen ini harus memperhatikan pembaca dan penggunaan kalimat. Selain itu, isi cerita itu harus diawali oleh paragraph pertama yang harus bisa menarik minat pembaca untuk menyelesaikan bacaannya, karena paragraf pertama merupakan etalase sebuah cerita (kunci pembuka). Pertimbangan suasana, bumbu-bumbu, tokoh. Fokus cerita, dan sentakan terakhir merupakan hal yang juga harus diperhatikan.

7) Setelah menulis cerita selesai, suntinglah kembali, buanglah kalimatkalimat yang kurang diperlukan. Kegiatan ini lebih baik dilakukan secara berulang-ulang.

8) Langkah terakhir yaitu memberi judul terhadap cerita yang telah selesai ditulis.

Berdasarkan uraian diatas dapat disimpulkan bahwa dalam menulis teks cerpen harus memiliki sebuah teknik menulis untuk dapat mengembangkan imajinasi saat menulis. Langkah-langkah menulis teks cerpen dapat diterapkan agar memudahkan kita dalam membuat sebuah cerita pendek.

\section{g. Teknik Penilaian dalam Menulis Teks Cerpen}

Teknik penilaian unsur-unsur cerita menurut Cooper dan Odell (dalam Darusuprapti, 2015) teknik penilaian unsur cerita meliputi 6 unsur cerita yaitu: (1) tema dan amanat, (2) tokoh dan penokohan, (3) alur, (4) setting tempat, (5) setting suasana, (6) setting waktu, (7) gaya penceritaan, (8) sudut pandang, (9) ekstrinsik cerita, (10) skruktur awal/pendahuluan, (11) struktur tengah/inti, dan (12) struktur akhir/penutup.

Ahmad Rofi'uddin dan Darmiyati Zuchdi (dalam Darusuprapti, 2015) mengemukakan unsur-unsur yang dinilai dalam keterampilan menulis meliputi 5 unsur cerita yaitu: (1) isi gagasan, (2) organisasi isi, (3) struktur tata bahasa, (4) gaya, dan (5) ejaan dan tanda baca. Dalam penelitian ini, peneliti menggunakan teknik penilaian yang dimodifikasi dari pendapat Enny Zubaidah, Ahmad Rofi'uddin, dan Darmiyati Zuchdi. Teknik penilaian unsur cerita dalam penelitian ini peliputi 6 unsur cerita yaitu: (1) tema, (2) tokoh dan penokohan, (3) alur, (4) setting, (5) amanat, dan (6) gaya penceritaa. 


\section{Hakikat Penguasaan Diksi}

\section{a. Penguasaan Diksi}

Diksi adalah bentuk serapan dari kata diction yang oleh Hornby diartikan sebagai choice and use of words (Jabrohim dalam Darusuprapti, 2015). Kamus Besar Bahasa Indonesia (2008), mengartikan diksi sebagai pilihan kata yang tepat dan selaras dalam penggunaanya untuk mengungkapkan gagasan, sehingga diperoleh efek tertentu seperti yang diharapkan. Penguasaan diksi seseorang akan mempengaruhi kegiatan berbahasanya, termasuk dalam kegiatan menulis dan berbicara.

Sukino (2010) menjelaskan diksi mengandung dua makna. Pertama, pilihan kata merupakan kemampuan membedakan secara tepat nuansa-nuansa makna sesuai dengan situasi dan gagasan yang ingin disampaikan, dan kemampuan untuk menemukan bentuk sesuai dengan situasi dan nilai rasa yang dimiliki kelompok masyarakat pendengar. Kedua, pilihan kata yang tepat dan sesuai dengan konteks kosa kata bahasa itu sendiri.

Semakin banyak kosa kata yang dimiliki seseorang tentu semakin mudah orang tersebut memilih dan menggunakan kata secara tepat. Berbeda dengan berbicara, dalam menulis seseorang memiliki peluang yang lebih banyak untuk memilih dan mempertimbangkan pilihan kata secara tepat sebelum tulisan tersebut dibaca orang lain. Untuk mendayagunakan diksi secara tepat, perlu diperhatikan ketepatan dan kesesuaian diksi.

1) Ketepatan diksi

Ketepatan pilihan kata mempersoalkan kesanggupan sebuah kata untuk menimbulkan gagasan-gagasan yang tepat pada imajinasi pembaca atau pendengar, seperti apa yang dipikirkan atau dirasakan oleh penulis (Keraf, 2010:87). Jika ketepatan diksi dalam suatu tulisan sesuai yang diinginkan penulis, maka akan timbul reaksi yang diinginkan penulis. Hal ini juga sejalan dengan pemikiran Mukh Doyin dan Wagiran (2009) ketepatan diksi tidak akan menimbulkan salah paham

2) Kesesuaian Diksi

Secara singkat perbedaan antara persoalan ketepatan dan 
kesesuaian adalah dalam persoalan ketepatan kita bertanya apakah pilihan kata yang dipakai sudah setepat-tepatnya, sehingga tidak akan menimbulkan interpretasi yang berlainan antara pembicara dan pendengar, atau antara penulis dan pembaca. Di dalam persoalan kecocokan atau kesesuaian apakah pilihan kata dan gaya bahasa yang dipergunakan tidak merusak suasana atau menyinggung perasaan orang lain.

\section{b. Indikator Penguasaan Diksi}

Berdasarkan uraian mengenai ketepatan dan kesesuaian diksi, maka dirumuskan lima indikator penguasaan diksi. Indikator-indikator tersebut adalah sebagai berikut.

1) Dapat membedakan kata denotatif dan konotatif

2) Dapat menentukan kata yang bersinonim

3) Dapat membedakan kata umum dan kata khusus

4) Dapat menggunakan kata-kata indra

5) Dapat membedakan kata-kata ilmiah dan populer

\section{Korelasi Penguasaan Diksi dengan Keterampilan Menulis Teks Cerpen}

Penguasaan diksi yang tepat akan menghasilkan teks yang menarik untuk dibaca/didengar. Sebaliknya jika penguasaan diksi tidak tepat, tulisan akan membingunkan pembaca. Jadi keterampilan menulis teks cerpen tergantung kepada bagaimana penulis dapat menggunakan diksi yang tepat. Oleh sebab itu penguasaan diksi penting dalam menulis teks cerpen. dengan demikian dapat ditarik suatu simpulan bahwa semakin bagus penguasaan diksi siswa maka akan semakin mudah siswa menulis teks cerpen.

\section{B. Kerangka Konseptual}

Secara konseptual terdapat korelasi antara variabel penguasaan diksi dan keterampilan menulis teks cerpen. Penguasaan diksi adalah variabel bebas (X), sedangkan keterampilan menulis teks cerpen adalah variabel terikat (Y). untuk lebih jelasnya digambarkan dalam kerangka konseptual berikut.

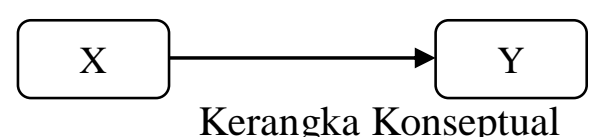

Kerangka Konseptual 
Keterangan:

$\mathrm{X}=$ Penguasaan Diksi

$\mathrm{Y}=$ Keterampilan Menulis Teks Cerpen

$\longrightarrow \quad=$ Korelasi

\section{Hipotesis Penelitian}

1. Hipotesis Nol

Tidak ada pengaruh antara penguasaan diksi terhadap keterampilan menulis teks cerpen siswa kelas X SMAN 2 Harau.

2. Hipotesis Kerja

Terdapat pengaruh signifikan antara penguasaan diksi terhadap keterampilan menulis teks cerpen siswa kelas X SMAN 2 Harau. 


\section{BAB III \\ METODELOGI PENELITIAN}

\section{A. Jenis Penelitian}

Jenis penelitian ini adalah penelitian kuantitatif. Menurut Arikunto (dalam Gusnita Roza Putri, Syahrul R., 2012) dikatakan penelitian kuantitatif karena data yang akan dianalisis berupa angka, mulai dari pengumpulan data, penafsiran terhadap data, dan penampilan hasilnya.

Metode yang digunakan adalah metode korelasional. Penelitian korelasional adalah penelitian yang menyelidiki ada tidaknya hubungan/ korelasi antara dua atau lebih variabel (Yeni $\mathrm{j}$ et al., 2018). Hubungan itu dinyatakan dengan koefisien korelasi yang sekaligus menunjukkan besar dan arah hubungan. Besarnya koefisien korelasi minimal -1 dan maksimal +1 . Koefisien korelasi positif menunjukkan hubungan yang berbanding lurus atau kesejajaran, sedangkan koefisien korelasi negatif menunjukkan hubungan berbanding terbalik atau ketidak-sejajaran.

\section{B. Populasi dan Sampel}

Populasi dalam penelitian ini adalah siswa kelas X SMA Negeri 2 Harau yang terdaftar pada tahun ajaran 2021/2022. Jumlah siswa kelas X pada semester ganjil 2021/2022 adalah sebanyak 120 orang yang tersebar di empat kelas. Sampel merupakan bagian populasi yang akan diteliti. Dikarenakan populasi penelitian lebih dari seratus siswa, maka perlu digunakan teknik pengambilan sampel. Pemilihan sampel ini dilakukan dengan teknik propertional simple random sampling (secara acak mengikuti jumlah kelas). Subjek dalam penelitian ini berjumlah lebih dari 100 .

Arikunto (dalam Gusnita Roza Putri, Syahrul R., 2012) menyatakan apabila subjek lebih dari 100, maka sampel diambil 10\%-15\% atau 20\%-25\%. Peneliti mengambil sampel sebanyak 20\% dari jumlah populasi per kelas. Populasi dan sampel tersebut dapat dilihat pada tabel berikut.

\begin{tabular}{|l|c|c|c|}
\hline No & Kelas & Populasi & Sampel \\
\hline 1 & X 1 & 30 orang & 6 orang \\
\hline 2 & X 2 & 30 orang & 6 orang \\
\hline 3 & X 3 & 30 orang & 6 orang \\
\hline 4 & X 4 & 30 orang & 6 orang \\
\hline \multicolumn{2}{|c|}{ Jumlah } & 120 orang & 24 orang \\
\hline
\end{tabular}




\section{Variabel dan Data}

Penelitian ini terdiri atas dua variabel, yaitu variabel bebas yang dilambangkan dengan huruf $\mathrm{X}$ dan variabel terikat yang dilambangkan dengan huruf $\mathrm{Y}$. Variabel bebas (X) pada penelitian ini adalah penguasaan diksi siswa kelas X SMA Negeri 2 Harau. Variabel terikat (Y) pada penelitian ini adalah keterampilan menulis teks cerpen siswa kelas X SMA Negeri 2 Harau. Data penelitian ini adalah skor hasil tes penguasaan diksi dan skor hasil tes keterampilan menulis teks cerpen siswa kelas X SMA Negeri 2 Harau.

\section{Instrumen Penelitian}

Instrumen yang digunakan dalam penelitian ini adalah berupa tes. Tes digunakan untuk mengukur tingkat penguasaan diksi siswa dan tes untuk mengukur keterampilan menulis teks cerpen siswa kelas X SMA Negeri 2 Harau. Bentuk tes yang digunakan dalam penelitian ini ada dua, yaitu tes objektif dan tes unjuk kerja.

\section{Tes Objektif}

Tes objektif digunakan untuk mengukur keterampilan penguasaan diksi siswa. Tes objektif yang digunakan berupa tes pilihan ganda untuk mengetahui seberapa kuat keterampilan penguasaan diksi siswa. Jumlah soal pilihan berganda sebanyak 20 soal untuk penguasaan diksi diberi skor satu (1) jika benar sedangkan jika salah diberi skor nol (0). Dikerjakan dengan memilih 'pilihan berganda' sehingga nilai tertinggi adalah 20 dan nilai terendah adalah 0 . Untuk lebih jelasnya kisi-kisi instrumen tersebut dapat dilihat pada tabel di bawah ini.

\begin{tabular}{|c|l|c|l|}
\hline No & \multicolumn{1}{|c|}{ Kisi-kisi } & Jumlah Soal & Nomor Soal \\
\hline 1 & $\begin{array}{l}\text { Membedakan kata denotatif dan } \\
\text { konotatif }\end{array}$ & 3 & $1,3,7$ \\
\hline 2 & $\begin{array}{l}\text { Menentukan kata yang } \\
\text { bersinonim }\end{array}$ & 2 & 2,10 \\
\hline 3 & $\begin{array}{l}\text { Membedakan kata umum dan } \\
\text { kata khusus }\end{array}$ & 5 & $4,6,9,14,18$ \\
\hline 4 & Menggunakan kata-kata indra & 5 & $\begin{array}{l}5,8,11,13, \\
15\end{array}$ \\
\hline 5 & $\begin{array}{l}\text { Membedakan kata-kata ilmiah } \\
\text { dan popular }\end{array}$ & 5 & $\begin{array}{l}12,16,17, \\
19,20\end{array}$ \\
\hline
\end{tabular}




\section{Tes Unjuk Kerja}

Tes unjuk kerja digunakan untuk mengumpulkan data keterampilan menulis teks cerpen siswa kelas X SMA Negeri 2 Harau. Melalui tes tersebut siswa diminta untuk menulis teks cerpen berdasarkan topik yang disediakan. Untuk memudahkan dalam melakukan penilaian hasil menulis cerita pendek maka perlu dibuat kisi-kisi penilaian dalam menulis cerita pendek. Untuk kisi-kisi penilaian menulis teks cerpen dapat dilihat pada tabel berikut.

\begin{tabular}{|c|l|c|}
\hline No & Unsur yang Dinilai & Skor \\
\hline 1 & Tema & 15 \\
\hline 2 & Tokoh & 20 \\
\hline 3 & Alur & 10 \\
\hline 4 & Setting cerita & 20 \\
\hline 5 & Amanat & 15 \\
\hline 6 & Gaya penceritaan & 20 \\
\hline \multicolumn{2}{|c|}{ Total } & 100 \\
\hline
\end{tabular}

\section{E. Teknik Pengumpulan Data}

Teknik pengumpulan data dalam penelitian ini dilakukan dengan dua cara sebagai berikut. Pertama, siswa diminta untuk mengerjakan tes objektif (pilihan ganda), terdapat 20 soal dilengkapi dengan lembar jawaban. Sesuai petunjuk soal, siswa diminta menyilang salah satu pilihan ganda pada lembar jawaban. Lembar jawaban kemudian dikumpulkan kembali untuk selanjutnya diolah berdasarkan teknik analisis data. Kedua, memberikan tes unjuk kerja untuk mengukur keterampilan menulis teks cerpen siswa. Siswa diminta untuk menuliskan teks cerpen dengan memperhatikan indikator menulis teks cerpen. Setelah selesai mengerjakan tes, tulisan siswa dikumpulkan dan dilakukan analisis sesuai dengan indikator penilaian tes unjuk kerja. 


\section{KEPUSTAKAAN}

Abidin, Y. (2016). Pembelajaran Menulis dalam Gamitan Pendidikan Karakter. EduHumaniora | Jurnal Pendidikan Dasar Kampus Cibiru, 4(1). https://doi.org/10.17509/eh.v4i1.2823.

Bagus, I. (2017). Bab II Kajian Pustaka, Kerangka Teoretis, dan Kerangka Berpikir 2.1. $20,10-39$.

Darusuprapti, F. (2015). Peningkatan Keterampilan Menulis Cerita Pendek Menggunakan Media Pop Up untuk Siswa Kelas IV SD Muhammadiyah Sidukarto $\begin{array}{llll}\text { Godean } & \text { Slemen } & \text { Yogyakarta. } & 3,\end{array}$ http://weekly.cnbnews.com/news/article.html?no=124000.

Doyin, Mukh dan Wagiran. 2009. Bahassa Indonesia: Pengantar Penulisan Karya Ilmiah. Semarang: Unnes Press.

Fajar Dwi Cahyaningrum, N. H. (2019). Jurnal Pendidikan Bahasa dan Sastra Indonesia. Jurnal Pendidikan Bahasa dan Sastra Indonesia, 1(1), 44-59.

Fitri, F., Mardian, M., \& Zulfahita, Z. (2019). Choose Your Clue Cards Learning Model in Writing Creative Cerpen Students of Indonesian Education and Literature Education STKIP Singkawang. AKSIS: Jurnal Pendidikan Bahasa dan Sastra Indonesia, 3(2), 267-274. https://doi.org/10.21009/aksis.030204.

Gusnita Roza Putri, Syahrul R., E. G. (2012). Hubungan Kemampuan Berpikir Logis dengan Kemampuan Menulis Karangan Argumen Siswa Kelas X SMA. Jurnal Pendidikan Bahasa dan Sastra Indonesia, 1(September 2012), 19-26. http://ejournal.unp.ac.id/index.php/pbs/article/view/195.

Homsaniwati, H. (2019). Pengaruh Kecerdasan Interpersonal dan Penguasaan Diksi terhadap Kemampuan Menulis Cerita Pendek. Diskursus: Jurnal Pendidikan Bahasa Indonesia, 1(02), 136. https://doi.org/10.30998/diskursus.v1i02.4398.

Keraf, Gorys. 2010. Diksi dan Gaya Bahasa. Jakarta: Gramedia.

Khulsum, U., Hudiyono, Y., \& Sulistyowati, E. D. (2018). Pengembangan Bahan Ajar Menulis Cerpen dengan Media Storyboard pada Siswa Kelas X SMA. DIGLOSIA : Jurnal Kajian Bahasa, Sastra, dan Pengajarannya, 1(1), 1-12. https://doi.org/10.30872/diglosia.v1i1.pp1-12.

Kurniawan, A. (2019). Hubungan antara Kebiasaan Membaca Karya Sastra dan 
Penguasaan Kosakata terhadap Keterampilan Menulis Cerpen Siswa Kelas XI SMA NEGERI Se- Kabupaten Gunungkidul.

Nengsi, Y. S., Basri, I., \& Tamsin, A. C. (2020). Kontribusi Kemampuan Membaca Apresiatif Teks Cerpen terhadap Keterampilan Menulis Teks Cerpen Siswa Kelas VII SMPN 26 Padang. Jurnal Pendidikan Bahasa dan Sastra Indonesia, 8(3), 496501.

Nur, M., Burhanuddin, B., \& Mannahali, M. (2021). Hubungan antara Penguasaan Kosakata dengan Keterampilan Menulis Puisi Bahasa Jerman. Interference: Journal of Language, Literature, and Linguistics, 2(1), 64-70.

Purwadi, A. J., \& Yulistio, D. (2021). Kemampuan Menulis Teks Cerpen Mahasiswa Program Sarjana Pendidikan Bahasa Indonesia Ability to Write Short Stories for Undergraduate Students in Indonesian Language Education A . Mahasiswa Calon Guru. 4(1), 60-79.

Purwahida, R. (2017). Interaksi Sosial pada Kumpulan Cerpen Potongan Cerita di Kartu Pos Karangan Agus Noor dan Implikasinya terhadap Pembelajaran Sastra di SMA. AKSIS: Jurnal Pendidikan Bahasa dan Sastra Indonesia, 1(1), 118-134. https://doi.org/10.21009/10.21009/aksis.010107.

Purwanti, G. E. (2016). Pembelajaran Menulis Teks Cerpen Berbasis Konflik dengan Menggunakan Metode Mind Mapping pada Siswa Kelas X SMAN 5 Cimahi Tahun Pelajaran 2015/2016. 14-40.

Rachman, Anita Kurnia, S., \& Lutfiyah, L. Z. (2020). Pemanfaatan Media Cerita Pendek dalam Menulis Naskah DramaSiswa SMP Kelas 8. 1-16. https://doi.org/10.21776/ub.hastawiyata.2020.003.01.06.

Ritonga, Fitriani (2016). Hubungan Penguasaan Diksi dengan Kemampuan Menulis Cerpen Siswa Kelas X SMA Swasta Annizam Medan Tahun Pembelajaran. Undergraduate thesis, UNIMED.

Rosmaya, E. (2018). Pembelajaran Menulis Teks Eksposisi dengan Menggunakan Pendekatan Kooperatif Tipe Investigasi Kelompok di SMP. Deiksis: Jurnal Pendidikan Bahasa dan Sastra Indonesia, 5(1), 111. https://doi.org/10.33603/deiksis.v5i1.999.

Sarudi, W. (2018). Penggunaan Media Kartu Gambar Berseri untuk Meningkatkan Kemampuan Menulis Cerpen Siswa Kelas IX G SMPN 3 Wates Kediri. Hasta Wiyata, 1(1), 52-61. https://doi.org/10.21776/ub.hastawiyata.2018.001.01.06. 
Silalahi, S. S. M. (2017). Hubungan Penguasaan Gaya Bahasa terhadap Kemampuan Menulis Cerpen oleh Siswa Kelas XI SMA Negeri 1 Kuala Tahun Pembelajaran $2017 / 2018$.

Simorangkir, Kartini (2017). Hubungan Penguasaan Diksi dengan Kemampuan Menulis Puisi Siswa Kelas IX SMP Negeri 4 Balige Tahun Pembelajaran 2016/2017. Undergraduate thesis, UNIMED.

Sufanti, M., Pengkajian, M., Pascasarjana, B., \& Surakarta, M. (2013). Pembelajaran Bahasa Indonesia Berbasis Teks : Belajar Dari Ohio. April, 36-55.

Sukino. 2010. Menulis itu Mudah: Panduan Praktis Menjadi Penuis Handal. Yogyakarta: Pustaka Populer

Sukirman. (2020). Tes Kemampuan Keterampilan Menulis dalam Pembelajaran Bahasa Indonesia di Sekolah. 9(2), 72-81.

Supadmi, Sri (2014) Minat Baca, Penguasaan Diksi, dan Keterampilan Menulis Narasi Siswa Kelas X SMA Negeri 4 Semarang Tahun Pelajaran 2012/2013. Thesis thesis, Universitas Muhammadiyah Surakarta.

Surastina, S. (2021). Hubungan Penguasaan Diksi dan Tanda Baca dengan Kemampuan Menulis Persuasi Siswa Kelas VIII SMPN 10 Bandar Lampung. Ksatra: Jurnal Kajian Bahasa dan Sastra, 2(2), 173-184. https://doi.org/10.52217/ksatra.v2i2.676.

Susetya, H. H. H. (2019). Multimedia Interaktif dengan Strategi Episodic Mapping untuk Pembelajaran Menulis Cerpen Siswa SMA. Hasta Wiyata, 2(1), 55-61. https://doi.org/10.21776/ub.hastawiyata.2018.002.01.06.

Yeni j, F., Zelhendri, Z., \& Darmansyah. (2018). Penilitian Pendidikan. 170. 